\title{
Dopamine agonist resistant prolactinomas: any alternative medical treatment?
}

\author{
P. Souteiro ${ }^{1,2,3,4,5,6}$ (D) N. Karavitaki ${ }^{4,5,6}$ (D)
}

Published online: 14 September 2019

(c) The Author(s) 2019

\begin{abstract}
Consensus guidelines recommend dopamine agonists (DAs) as the mainstay treatment for prolactinomas. In most patients, DAs achieve tumor shrinkage and normoprolactinemia at well tolerated doses. However, primary or, less often, secondary resistance to DAs may be also encountered representing challenging clinical scenarios. This is particularly true for aggressive prolactinomas in which surgery and radiotherapy may not achieve tumor control. In these cases, alternative medical treatments have been considered but data on their efficacy should be interpreted within the constraints of publication bias and of lack of relevant clinical trials. The limited reports on somatostatin analogues have shown conflicting results, but cases with optimal outcomes have been documented. Data on estrogen modulators and metformin are scarce and their usefulness remains to be evaluated. In many aggressive lactotroph tumors, temozolomide has demonstrated optimal outcomes, whereas for other cytotoxic agents, tyrosine kinase inhibitors and for inhibitors of mammalian target of rapamycin (mTOR), higher quality evidence is needed. Finally, promising preliminary results from in vitro and animal reports need to be further assessed and, if appropriate, translated in human studies.
\end{abstract}

Keywords Prolactinoma $\cdot$ Dopamine agonist $\cdot$ Resistance $\cdot$ Aggressive prolactinoma

\section{Introduction}

Prolactinomas are the most common pituitary neuroendocrine tumors (PitNETs) with a prevalence ranging from 6-10 to 60 per 100,000 patients [1-3]. Most of them arise from monoclonal expansion of lactotroph cells. Less than $5 \%$

N. Karavitaki

n.karavitaki@bham.ac.uk

1 Department of Endocrinology, Diabetes and Metabolism, Centro Hospitalar Universitário de São João, Porto, Portugal

2 Faculty of Medicine of University of Porto, Porto, Portugal

3 Instituto de Investigação e Inovação em Saúde, University of Porto, Porto, Portugal

4 Institute of Metabolism and Systems Research (IMSR), College of Medical and Dental Sciences, University of Birmingham, IBR Tower, Level 2, Birmingham B15 2TT, UK

5 Centre for Endocrinology, Diabetes and Metabolism, Birmingham Health Partners, Birmingham, UK

6 Department of Endocrinology, Queen Elizabeth Hospital, University Hospitals Birmingham NHS Foundation Trust, Birmingham, UK of the cases are related to a hereditary syndrome, such as Multiple Endocrine Neoplasia 1 and 4 (MEN1 and MEN4, respectively), familial isolated pituitary adenoma (FIPA) or Carney complex [4-6].

The clinical manifestations of prolactinomas relate to mass-effects (most frequently visual field defects, headaches and hypopituitarism) and/or to hyperprolactinemiarelated consequences (hypogonadism and its sequelae and galactorrhea). Primary goals of treatment are reduction in tumor size, achievement of normal prolactin and restoration of gonadal function $[7,8]$. The treatment of prolactinomas is unique amongst the PitNETs, since they are the only type of pituitary tumor in which first-line approach is medical therapy [with dopamine agonists (DA)] rather than surgery. Consensus guidelines recommend cabergoline in preference to other DAs, such as bromocriptine and quinagolide [7]. This is based on studies showing more optimal tolerability profile and higher efficacy in achieving normoprolactinemia and tumor shrinkage with this agent [9-12], attributed to higher affinity to D2 receptor and more potent cytocidal effect in tumor cells (compared with bromocriptine) [13]. In addition, a meta-analysis has underlined that DAs, in this case bromocriptine, can successfully manage various clinical 
manifestations seen in patients with prolactinoma, including $86 \%$ of those with galactorrhea, $78 \%$ with amenorrhea, $67 \%$ with sexual dysfunction, $67 \%$ with visual field defects and $53 \%$ of patients with infertility [14].

A small subset of patients does not respond to DAs (primary resistance). It should be noted, however, that definitions of resistance are highly variable throughout the literature, rendering the comparison of response rates and relevant predictors rather challenging. Practice guidelines for hyperprolactinemia suggest that a failure to achieve normal prolactin on maximally tolerated doses of DAs and a failure to achieve 50\% reduction in tumor size should be regarded as DA-resistance [7]. This definition has also been acknowledged by the other publications $[15,16]$. The maximally tolerated doses vary amongst patients and can be up to $12 \mathrm{mg}$ weekly for cabergoline and $30 \mathrm{mg}$ daily for bromocriptine [15-17]. In common clinical practice, the mean maximum dose of cabergoline (the most frequently used DA) is around $4 \mathrm{mg}$ per week [18]. There is no agreement on the minimum duration of treatment and it would seem reasonable to suggest at least 6 months on the highest tolerated DA dose [17]. It is also worth mentioning that the relative importance of tumor shrinkage as a criterion for resistance needs to be challenged in adenomas in which, although reduction in size has not been achieved, they are not causing pressure effects. Consensus recommendations recognize that failure to restore fertility may also reflect treatment resistance, and that some patients might have a discordant biochemical and tumoral response, further complicating the establishment of a standard definition [7]. It should be further underlined that previous studies have used different cut-offs, such as $50 \%$ decrease in prolactin levels or $30 \%$ reduction in craniocaudal diameter of the tumor $[19,20]$. Irrespective of the criteria adopted for defining DA resistance, decisions on continuing treatment with these agents should also rely on the clinical benefit (e.g. restoration of gonadal function, resolution of mass effects and particularly visual disturbances, absence of tumor growth) achieved for each individual patient.

Primary DA-resistance has been reported in approximately $20-30 \%$ of the patients on bromocriptine, and in around $10 \%$ of those on cabergoline $[15,17,21]$. Yet, when focusing on macroprolactinomas only, cabergoline fails to lead to normoprolactinemia in $17 \%$ of the cases and to tumor shrinkage in $29 \%$ of them [15]. Further studies have suggested that tumor size and invasiveness (namely cavernous sinus extension), younger age at diagnosis and male gender are predictors of lower response [18, 22-24]. Decreased expression of D2 dopamine receptors in tumor cells, alterations in other receptors modulating dopamine receptors [e.g. nerve growth factor receptor (NGFR)], changes in downstream cascades (e.g. in G protein subunit), increased angiogenic markers, and increased fibrosis through disruptions in the transforming growth factor
(TGF)- $\beta 1$ pathway have all been suggested as possible mechanisms playing a role in DA-resistance [25-29]. However, an extensive audit of these mechanisms is outside the scope of this review.

Secondary (or acquired) resistance to DAs is very rare and describes patients that initially responded to DA but later showed increasing prolactin levels and/or tumor enlargement. It should be pointed out that some patients who initially responded to bromocriptine but then acquired some degree of resistance have benefited from a switch to cabergoline, and, therefore, they should not be regarded as truly DA-resistant [30]. To the best of our knowledge, only six cases in the literature have reported true secondary DA-resistance, in some of them 10 years after an initial response [31-35]. The histologic characteristics of these tumors were heterogenous, ranging from adenomas without worrisome features to atypical adenomas with a high cell proliferation index. It is unknown if the mechanisms underlying secondary DA-resistance differ from those associated with primary resistance.

Current practice guidelines recommend several possible approaches for patients with DA-resistant prolactinomas [7]. In cases resistant to bromocriptine, a switch to cabergoline is recommended, based on the superior results of this agent when compared to other DAs, as previously discussed, and on studies reporting prolactin normalization in $80-85 \%$ of the patients after this change [11, 36]. Switch to quinagolide can not be excluded, although a meta-analysis found no differences when bromocriptine and quinagolide were compared for various clinical and biochemical outcomes [37]. Surgical removal is a further approach with remission rates of $63-72 \%$ and $32-60 \%$ for micro- and for non-invasive macroprolactinomas, respectively; these rates also include patients offered surgery due to DA intolerance $[38,39]$. Radiotherapy is an alternative option with studies reporting normoprolactinemia rates of $15-50 \%$ that can be further increased when DA therapy is added (40-100\%) [40]. Malignant and aggressive prolactinomas represent a rare and difficult setting of DA-resistance posing significant therapeutic challenges [41, 42].

The above described options to overcome DA-resistance may not always be successful and in this setting, the value of alternative medical agents has been investigated. In the following sections, we have reviewed the available literature on different pharmacological options in DA-resistant prolactinomas. 


\section{Alternative medical treatments}

\section{Somatostatin analogues}

Somatostatin analogues (SSAs) have a well-defined role in the management algorithms of corticotropinomas, somatotropinomas and thyreotropinomas [43-45].

Immunochemistry mapping of somatostatin receptors (SSTR) has revealed that all SSTR types are present in prolactinomas; $\mathrm{SSTR}_{5}$ were particularly frequent, followed by SSTR $_{2 \mathrm{~A}}$ and $\mathrm{SSTR}_{1}$ [46-48]. However, clinical studies on the use of SSAs in prolactinomas have shown conflicting results. In the largest published case series, Sosa-Eroza et al. presented five patients with DA-resistant prolactinoma treated with octreotide LAR $(20 \mathrm{mg}$ for 6-13 months) in addition to cabergoline. Normoprolactinemia was not achieved in any of the patients but two of them had $>80 \%$ drop in prolactin and a $>90 \%$ reduction in tumor volume. The remaining three had no significant benefit [49]. A summary of the reported cases from the literature highlighting the mixed outcomes is shown in Table 1 [50-53].

A theoretical advantage of the second-generation SSA pasireotide over the first-generation ones (octreotide and lanreotide) could be postulated, considering its greater affinity for $\mathrm{SSTR}_{5}$. Nevertheless, in vitro analyses have provided conflicting results $[47,54,55]$. The first report of a patient with prolactinoma treated with pasireotide was recently published, presenting a case not controlled after treatment with the three available DAs and undergoing two surgical procedures (Table 1) [56]. Pasireotide was then tried, achieving prolactin normalization in one month and tumor stabilization that persisted during the 7-year follow-up. No side effects were reported apart from slight deterioration of glycemic control (HbA1c increased from 5.7 to 6.2\%). After this report, a second one described a DA-resistant macroprolactinoma also successfully treated with this agent [57]; considering that the tumor had a higher immunoreactivity score for $\mathrm{SSTR}_{5}$ than for $\mathrm{SSTR}_{2}$, and after attempting lanreotide Autogel without biochemical/imaging success, pasireotide was used leading to normoprolactinemia and tumor shrinkage. Once again, minor hyperglycemia was the only side effect reported (HbA1c increased from 5.4 to 6.3\%).

It has been previously demonstrated that the $\mathrm{SSTR}_{1}$ subtype is overexpressed in DA-resistant tumors suggesting that this could be a promising therapeutic target [47]. Despite this finding, an in vitro study showed that a SSTR ligand was not highly effective in suppressing prolactin levels and the role of this receptor in prolactin secretion is still not completely understood [47].

All the aforementioned studies include a small number of patients not allowing identification of predictors of response to SSA treatment. However, it seems likely that the SSTR expression profile in lactotroph adenomas is not the only parameter associated with the high variability in the outcomes. Other less well-understood aspects of SSTR biology, such as receptor homo- and hetero- dimerization and additional downstream pathways may also play a role [58]. Further methodologically sound studies are required to clarify the place of SSAs in the treatment algorithm of DA-resistant prolactinomas. Until then, a therapeutic trial in selected patients with aggressive and DA-resistant prolactinomas could be considered as a possible option.

\section{Estrogen modulators}

Estrogens stimulate prolactin secretion and lactotroph cell proliferation $[59,60]$. Lactotroph hyperplasia leading to gland enlargement during pregnancy and breast-feeding support these findings and suggests that estrogens may be potential therapeutic targets in prolactinomas [61]. On the other hand, it is of note that prolactinomas in men are characterized by lower estrogen receptor alpha $(E R \alpha)$ expression which is related to higher tumor grades, resistance to treatment, and an overall worse prognosis [62].

A number of studies have evaluated the potential role of selective estrogen receptor modulators (SERMs) in prolactinoma patients (Table 2). Tamoxifen was used in 10 women previously considered bromocriptine-resistant, inducing a moderate reduction of prolactin in 6 of them [63]. Two smaller studies conducted in the pre-cabergoline era and including patients not clearly fulfilling the DA resistance criteria showed inconsistent results on the efficacy of this drug [64, 65]. Raloxifene, another SERM, resulted in minimal decrease in prolactin levels (mean reduction of $8.3 \mathrm{ng} / \mathrm{mL}$ ) in 10 out of 14 patients, with the remaining ones considered as non-responders [66]. The drug was then stopped in 8 of them, as the absolute change in prolactin values was felt to be too small to justify this treatment. Fluvestrant, a selective estrogen receptor degrader (SERD) without the agonist properties of SERMs, inhibited prolactin secretion in rat prolactinoma models, but its usefulness in patients remains to be determined in clinical studies [37, 67-69].

Aromatase inhibition blocks the conversion of testosterone to estradiol and it could possibly mitigate the estrogeninduced lactotroph proliferation [70]. A higher expression of this enzyme in prolactinomas and its correlation with tumor invasiveness has been previously shown, but this has not been confirmed in DA-resistant prolactinomas in males $[71,72]$. Fadrozole administration in rats inhibited the proliferation of prolactin-positive cells and led to reduced prolactin levels [73]. Two publications have reported optimal outcomes with the use of aromatase inhibitors in DA-resistant patients with persistent hypogonadism [74, 75]. In the first case, prolactin increased after testosterone was added 
Table 1 Somatostatin analogues treatment in DA-resistant prolactinomas

\begin{tabular}{|c|c|c|c|c|c|c|c|}
\hline Study & $\begin{array}{l}\text { No. of } \\
\text { patients }\end{array}$ & Tumor & $\begin{array}{l}\text { Previous treat- } \\
\text { ments }\end{array}$ & SSA regime & $\begin{array}{l}\text { Duration of treat- } \\
\text { ment }\end{array}$ & $\begin{array}{l}\text { Normal PRL (\% } \\
\text { change in PRL } \\
\text { from baseline) }\end{array}$ & $\begin{array}{l}\text { Tumor shrink- } \\
\text { age (\% volume } \\
\text { change) }\end{array}$ \\
\hline \multirow[t]{5}{*}{$\begin{array}{l}\text { Soza-Eroza et al. } \\
\text { [47] }\end{array}$} & \multirow[t]{5}{*}{5} & \multirow[t]{5}{*}{$\begin{array}{l}\text { DA-resistant } \\
\text { macroprolacti- } \\
\text { nomas }\end{array}$} & $\begin{array}{l}\text { CBG (max } \\
4.5 \text { mg/week), } \\
\text { surgery, TMZ, } \\
\text { RT, tamoxifen }\end{array}$ & \multirow[t]{5}{*}{$\begin{array}{l}\text { Octreotide LAR } \\
(20 \mathrm{mg} / \mathrm{month})\end{array}$} & 12 months & No $(+3 \%)$ & Minor (- 9\%) \\
\hline & & & $\begin{array}{l}\text { CBG (max } 3 \mathrm{mg} / \\
\text { week) }\end{array}$ & & 13 months & No $(+1 \%)$ & Minor (- 5\%) \\
\hline & & & $\begin{array}{c}\text { CBG (max } 3 \mathrm{mg} / \\
\text { week), surgery }\end{array}$ & & 10 months & No $(-97 \%)$ & Yes $(-93 \%)$ \\
\hline & & & $\begin{array}{l}\text { CBG (max } \\
4.5 \mathrm{mg} / \text { week), } \\
\text { surgery }\end{array}$ & & 10 months & No $(-82 \%)$ & Yes $(-94 \%)$ \\
\hline & & & $\begin{array}{l}\text { CBG (max } \\
7.5 \mathrm{mg} / \text { week), } \\
\text { surgery }\end{array}$ & & 3 months & No $(+5 \%)$ & Minor $(-10 \%)$ \\
\hline Fusco et al. [48] & 1 & $\begin{array}{l}\text { DA-resistant } \\
\text { macroprolacti- } \\
\text { noma }\end{array}$ & $\begin{array}{c}\text { CBG (max } 3 \mathrm{mg} / \\
\text { week), surgery }\end{array}$ & $\begin{array}{l}\text { Octreotide LAR } \\
(20 \mathrm{mg} / \mathrm{month})\end{array}$ & NS & Yes & No \\
\hline \multirow[t]{2}{*}{ Walker et al. [49] } & \multirow[t]{2}{*}{2} & \multirow[t]{2}{*}{$\begin{array}{l}\text { DA-resistant } \\
\text { lactotroph carci- } \\
\text { nomas }\end{array}$} & $\begin{array}{l}\text { BRC (max } 30 \mathrm{mg} / \\
\text { day), surgery, } \\
\text { RT, CTX }\end{array}$ & $\begin{array}{l}\text { Octreotide } \\
(100 \mu \mathrm{g} \\
\text { 8-hourly })\end{array}$ & NS & No & No \\
\hline & & & $\begin{array}{l}\text { BRC (max } 20 \mathrm{mg} / \\
\text { day), surgery, } \\
\text { RT }\end{array}$ & NS & NS & NS & NS \\
\hline Baldari et al. [50] & 1 & $\begin{array}{l}\text { DA-resistant } \\
\text { macroprolacti- } \\
\text { noma }\end{array}$ & $\begin{array}{l}\text { BRC (max dose } \\
\text { NS), CBG } \\
(0.5 \mathrm{mg} / \text { week), } \\
\text { surgery, RT }\end{array}$ & $\begin{array}{l}\text { Octreotide LAR } \\
\text { (30 mg single } \\
\text { dose) }\end{array}$ & Single dose & No & No \\
\hline $\begin{array}{l}\text { Giuffrida et al. } \\
\text { [51] }\end{array}$ & 1 & $\begin{array}{l}\text { DA-resistant } \\
\text { macroprolacti- } \\
\text { noma }\end{array}$ & $\begin{array}{l}\text { CBG (max dose } \\
\text { NS), surgery, } \\
\text { RT }\end{array}$ & $\begin{array}{l}\text { Octreotide LAR } \\
\text { (30 mg single } \\
\text { dose })\end{array}$ & Single dose & No & No \\
\hline \multirow[t]{2}{*}{$\begin{array}{l}\text { Coopmans et al. } \\
\text { [55] }\end{array}$} & \multirow[t]{2}{*}{1} & \multirow[t]{2}{*}{$\begin{array}{l}\text { DA-resistant } \\
\text { macroprolacti- } \\
\text { noma }\end{array}$} & \multirow{2}{*}{$\begin{array}{l}\text { BRC (max } \\
7.5 \mathrm{mg} \text { /day), } \\
\text { CBG (max } \\
7 \text { mg/week), } \\
\text { surgery, RT }\end{array}$} & $\begin{array}{l}\text { Lanreotide Auto- } \\
\text { gel (120 mg/ } \\
\text { month) }\end{array}$ & 10 months & No $(+36 \%)$ & No \\
\hline & & & & $\begin{array}{l}\text { Pasireotide LAR } \\
(60 \mathrm{mg} / \mathrm{month} \\
\text { after lanreotide } \\
\text { was discontin- } \\
\text { ued) }\end{array}$ & 31 months & Yes $(-100 \%)$ & Yes $(-72 \%)$ \\
\hline Lasolle et al. [54] & 1 & $\begin{array}{l}\text { DA-resistant } \\
\text { macroprolacti- } \\
\text { noma }\end{array}$ & $\begin{array}{l}\text { BRC (max } 25 \mathrm{mg} / \\
\text { day), QNG } \\
\text { (max } 225 \mu \mathrm{g} / \\
\text { day), CBG } \\
\text { (4.5 mg/week), } \\
\text { surgery }\end{array}$ & $\begin{array}{l}\text { Pasireotide LAR } \\
\text { (initially } 60 \mathrm{mg} \\
\text { every } 28 \text { days, } \\
\text { then } 20 \mathrm{mg} \\
\text { every } 5 \text { weeks) }\end{array}$ & 7 years & Yes & No \\
\hline
\end{tabular}

A plus sign (+) in the PRL and volume changes indicate an increase in prolactin levels or tumor size, respectively, while a minus sign (-) imply a decrease in these variables

$S S A$ somatostatin analogue, $P R L$ prolactin, $D A$ dopamine agonist, $C B G$ cabergoline, $T M Z$ temozolomide, $R T$ radiotherapy, $L A R$ long-acting release, $N S$ not stated, $B R C$ bromocriptine, $C T X$ chemotherapy, $Q N G$ quinagolide

to cabergoline therapy. Anastrozole (1 mg daily) was then started and prolactin levels dropped by $80 \%$ in 3 months. Tumor size change was not reported [74]. In the second patient, a 36-year-old male, the introduction of testosterone replacement and human chorionic gonadotropin (hCG) therapy (in order to achieve fertility) led to raised prolactin levels. Letrozole ( $2.5 \mathrm{mg}$ daily) was tried leading to a $74 \%$ decrease in prolactin after 32 months, improved sperm count and fertility [75]. In both cases, authors hypothesized that testosterone aromatization to estradiol and subsequent 
Table 2 Selective estrogen receptor modulators $(S E R M)$ treatment in prolactinomas

\begin{tabular}{|c|c|c|c|c|c|c|c|}
\hline Study & No. of patients & Tumor & $\begin{array}{l}\text { Previous treat- } \\
\text { ments }\end{array}$ & Drug regime & $\begin{array}{l}\text { Duration of } \\
\text { treatment }\end{array}$ & $\begin{array}{l}\% \text { Change } \\
\text { in PRL from } \\
\text { baseline }\end{array}$ & $\begin{array}{l}\text { Tumor shrink- } \\
\text { age (\% volume } \\
\text { change) }\end{array}$ \\
\hline Volker et al. [60] & 10 & $\begin{array}{l}\text { DA-resistant } \\
\text { prolactinomas }\end{array}$ & $\begin{array}{l}\text { BRC (median } \\
\text { dose } 5 \mathrm{mg} / \\
\text { day), Surgery } \\
(\mathrm{n}=2)\end{array}$ & $\begin{array}{l}\text { Tamoxifen } \\
(10-20 \mathrm{mg} / \\
\text { day) }\end{array}$ & 4 weeks & $\begin{array}{l}\text { Mean }-35 \% \\
\quad \text { (Normal PRL } \\
\text { in 60\%) }\end{array}$ & NS \\
\hline $\begin{array}{l}\text { Lamberts et al. } \\
\text { [61] }\end{array}$ & 2 & $\begin{array}{l}\text { Prolactinomas } \\
\text { (not DA- } \\
\text { resistant) }\end{array}$ & NS & $\begin{array}{l}\text { BRC vs. BRC/ } \\
\text { Tamofixen } \\
\text { (20 mg/day) }\end{array}$ & $36 \mathrm{~h}$ & $45 \%$ vs. $-44 \%$ & NS \\
\hline $\begin{array}{l}\text { Lamberts et al. } \\
\text { [62] }\end{array}$ & 8 & $\begin{array}{l}\text { Invasive prolac- } \\
\text { tinomas (not } \\
\text { DA-resistant) }\end{array}$ & surgery $(n=6)$ & $\begin{array}{l}\text { Tamoxifen } \\
(20 \mathrm{mg} / \text { day })\end{array}$ & 5 days & Mean-20\% & NS \\
\hline $\begin{array}{l}\text { Choudhary et al. } \\
\text { [63] }\end{array}$ & 14 & $\begin{array}{l}\text { Prolactinomas } \\
\text { (not DA- } \\
\text { resistant) }\end{array}$ & $\begin{array}{l}\text { CGB (median } \\
\text { dose } 3 \mathrm{mg} / \\
\text { week) }(\mathrm{n}=13) \text {, } \\
\text { BRC }(15 \mathrm{mg} / \\
\text { day) }(\mathrm{n}=1)\end{array}$ & $\begin{array}{l}\text { Raloxifene } \\
\quad(60 \mathrm{mg} / \text { day })\end{array}$ & Mean 3 months & Mean-15\% & NS \\
\hline
\end{tabular}

A plus sign (+) in the PRL and volume changes indicate an increase in the prolactin levels or tumor size, respectively, while a minus sign (-) imply a decrease in these variables

$P R L$ prolactin, $D A$ dopamine agonist, $B R C$ bromocriptine, $N S$ not stated, $C B G$ cabergoline

estrogen-stimulated prolactin release were the main drives for the prolactin levels increase and that aromatase inhibitors blocked this effect.

Overall, data on the use of estrogen modulators in prolactinomas not responding to DAs are limited and inconclusive.

\section{Metformin}

Recently, metformin has attracted attention as a drug able to reduce lactotroph cells proliferation and to promote their apoptosis, both in rat xenografts and in human prolactinoma cell cultures [76, 77]. Metformin-dependent activation of AMP-activated protein kinase (AMPK) has been proposed as the underlying mechanism in accordance with the action of metformin in other types of tumors [78]. The cascade of events downstream the AMPK activation leading to the above effects are not fully understood, but estrogen receptor downregulation seems to be involved [77].

To date, only one study has described two bromocriptineresistant prolactinoma patients (on maximum dose of $15 \mathrm{mg}$ / day) treated with metformin [79]. In the first case, a patient with prolactin levels fluctuating between 70 and $488 \mathrm{ng} /$ $\mathrm{mL}$ was started metformin (1500 mg/day) after the diagnosis of diabetes mellitus and her prolactin was decreased to $56 \mathrm{ng} / \mathrm{mL}$ in 3 months and to $28 \mathrm{ng} / \mathrm{mL}$ in 5 months. Tumor shrinkage was also reported on both MRIs performed 5 and 10 months after drug initiation. Based on these findings, metformin was tried in a second patient of the same center. He presented with a giant prolactinoma that exhibited a good biochemical response to bromocriptine (prolactin levels decreased from 1293 to $17.7 \mathrm{ng} / \mathrm{mL}$ ) but without tumor shrinkage. After starting metformin, prolactin levels decreased to $2.08 \mathrm{mg} / \mathrm{dL}$ in 3 months and a $40 \%$ reduction in tumor volume (also associated with hemorrhage) was observed.

\section{Temozolomide}

Temozolomide (TMZ) is considered the first-line chemotherapeutic agent for aggressive pituitary tumors and carcinomas [80-82]. TMZ treatment has been reported in more than 30 lactotroph invasive adenomas/carcinomas, with approximately $50 \%$ of the patients exhibiting a decrease of more than $30 \%$ in tumor volume [83, 84].Several reports have shown dramatic improvements including disappearance of metastases, substantial primary tumor reduction and normalization of prolactin [80, 85-88]. Various regimens have been used and the administration of $50-200 \mathrm{mg} / \mathrm{m}^{2}$ for five days in 28 days cycles is the most frequently described protocol [83]. However, a second course of TMZ, even in patients previously considered as responders, has shown less favorable outcomes [89-91]. Amongst those cases, two lactotroph aggressive tumors/carcinomas were identified in which TMZ initial therapy led to good results, ranging from a remarkable $98 \%$ reduction in prolactin levels to a $25 \%$ regression in tumor size. However, when these tumors progressed and a second course of TMZ was offered, the results were disappointing, suggesting an acquired TMZ-resistance mechanism that remains to be fully clarified [89, 90].

Several studies have looked at possible predictors of TMZ response in pituitary tumors. A lower expression of O6-methylguanine-DNA methyltransferase (MGMT), a 
DNA-repair protein that counteracts the effects of TMZ, is significantly correlated with the effectiveness of the drug [89, 92, 93]. This observation led to the recommendation of routinely determining the MGMT status in all aggressive pituitary tumors by immunochemistry [81]. Additionally, response to TMZ in the first 3 months of treatment is considered a useful predictor of and drug discontinuation is advised if radiological progression is demonstrated after that interval [80, 81]. On the other hand, Ki-67 labelling index and p53 protein expression have not been confirmed to be of value in this setting $[83,92]$.

\section{Other cytotoxic agents}

Cytotoxic agents other than TMZ have been rarely used in the treatment of aggressive pituitary tumors and carcinomas and the experience with these drugs is limited to isolated case reports. Amongst them, lomustine and 5-fluorouracil are the most frequently offered due to their ability to penetrate the central nervous system. In a series reporting four lactotroph-derived tumors (three carcinomas and one locally invasive adenoma), all of them previously surgically managed and considered DA-resistant, this combination led to a partial response only in the least aggressive one [94]. Other studies described combinations of different chemotherapeutic agents, such as procarbazine and vincristine without therapeutic success $[95,96]$.

\section{Tyrosine kinase inhibitors}

The epidermal growth factor receptor (EGFR) pathway has attracted interest as a potential therapeutic target for resistant and aggressive pituitary tumors, mainly lactotroph and corticotroph ones [97]. Several receptor subtypes from this family have been identified in prolactinomas, and different expression profiles have been associated to tumor invasiveness, symptoms, and response to DAs [98, 99]. Notably, a higher expression of the ErbB3 receptor of this family in prolactinomas was associated with optic chiasm compression, suprasellar extension, carotid artery encasement, and with a better response to DA treatment [99].

Tyrosine kinase inhibitors (TKIs) block EGFR signal transduction cascades and in primary cultures of human prolactinomas, they reduce prolactin levels [100]. Two DAresistant patients with aggressive lactotroph tumors have received treatment with lapatinib for a 6-month period. The first case achieved near normalization of prolactin and a $22 \%$ reduction in tumor volume, while the second one demonstrated a $42 \%$ reduction in prolactin levels and tumor stabilization [99]. These encouraging results are currently further explored in an ongoing phase II clinical trial in patients with DA-resistant prolactinomas [101]. Bevacizumab, a TKI targeting vascular endothelial growth factor (VEGF), has shown to partially suppress the proliferation of tumor stem-like cells isolated from rat prolactinoma [102]. This compound showed promising results in the treatment of corticotroph carcinomas but there is still no reported experience with prolactinomas [103, 104].

\section{Inhibitors of mammalian target of rapamycin (mTOR)}

The PI3K/Akt/mTOR pathway is an intracellular signaling system regulating the cell cycle and its overactivity has been associated with several cancers [105]. Anti-proliferative responses to the inhibition of the mammalian target of rapamycin (mTOR) pathway have been reported in in vitro studies with aggressive pituitary tumors [106]. Particularly for prolactinomas, Gorvin et al. showed that certain variants of the prolactin receptor, like the Asn492Ile one, are associated with increased signaling by this pathway and cellular proliferation, and that everolimus was antagonizing these effects [107]. A case report described a patient with a DA-resistant prolactinoma that underwent multiple surgical resections and radiotherapy 6 years before a trial of everolimus $(10 \mathrm{mg} /$ day) was attempted [108]. After starting this agent, a 44\% decrease in prolactin levels was observed and tumoral size was stable at the 1-year imaging re-evaluation. In this case, hyperglycemia, hypogeusia and mouth sores were reported as side effects. However, the same drug has been associated with disappointing outcomes in patients with aggressive corticotroph adenomas, underlining the need for larger studies [109, 110].

\section{Other pharmacologic agents}

In addition to the aforementioned drug classes, there are others described as potentially useful in the treatment DAresistant prolactinomas with evidence based only on preclinical studies.

The TGF- $\beta 1$ cytokine is intimately associated with fibrotic responses in different organs and tissues. $\mathrm{Hu}$ et al. reported that about $43 \%$ of the DA-resistant prolactinomas were highly fibrotic and had a higher collagen content than the DA-responsive ones [79]. In addition, the expression of TGF- $\beta 1 / \mathrm{Smad} 3$ signaling pathway-related proteins was elevated in DA-resistant and fibrotic prolactinomas and the compound SB431542, an inhibitor of this pathway, counteracted these effects. A further publication reinforced these results, but others have reported opposite outcomes [29, 111, $112]$. No studies in prolactinoma patients have been yet conducted with this drug.

A single study showed that chloroquine, an old drug used in malaria treatment, enhanced cabergoline-induced autophagy and apoptosis in prolactinoma cells in vitro [113]. The same paper also investigated two animal models 
in which chloroquine increased tumor suppression, allowing cabergoline to exert its effects at a lower dose. The significance of these findings in clinical practice remain to be elucidated.

\section{Conclusions and future perspectives}

Primary or secondary resistance to DAs represent challenging clinical scenarios. This is particularly true for aggressive prolactinomas in which surgery and radiotherapy may not achieve tumor control. In these settings, alternative medical treatments have been considered but data on their efficacy should be interpreted within the constraints of publication bias and of lack of relevant clinical trials. The limited reports on SSAs have shown conflicting results, but, nonetheless, cases with optimal outcomes have been documented. Data on estrogen modulators and metformin are scarce and their usefulness remains to be evaluated. In aggressive lactotroph PitNETs, temozolomide has demonstrated optimal outcomes, whereas for other cytotoxic agents, TKIs and for mTOR inhibitors, higher quality evidence is needed. Finally, promising preliminary results from in vitro and animal reports need to be validated and translated in human studies.

\section{Compliance with ethical standards}

Conflict of interest N. Karavitaki has received educational and research Grants from Novartis, Pfizer and Ipsen.

Open Access This article is distributed under the terms of the Creative Commons Attribution 4.0 International License (http://creativecommons.org/licenses/by/4.0/), which permits unrestricted use, distribution, and reproduction in any medium, provided you give appropriate credit to the original author(s) and the source, provide a link to the Creative Commons license, and indicate if changes were made.

\section{References}

1. Ciccarelli A, Daly AF, Beckers A (2005) The epidemiology of prolactinomas. Pituitary 8(1):3-6. https://doi.org/10.1007/s1110 2-005-5079-0

2. Fernandez A, Karavitaki N, Wass JA (2010) Prevalence of pituitary adenomas: a community-based, cross-sectional study in Banbury (Oxfordshire, UK). Clin Endocrinol 72(3):377-382. https://doi.org/10.1111/j.1365-2265.2009.03667.x

3. Daly AF, Rixhon M, Adam C, Dempegioti A, Tichomirowa MA, Beckers A (2006) High prevalence of pituitary adenomas: a cross-sectional study in the province of Liege, Belgium. J Clin Endocrinol Metab 91(12):4769-4775. https://doi.org/10.1210/ jc.2006-1668

4. Herman V, Fagin J, Gonsky R, Kovacs K, Melmed S (1990) Clonal origin of pituitary adenomas. J Clin Endocrinol Metab 71(6):1427-1433. https://doi.org/10.1210/jcem-71-6-1427
5. Daly AF, Jaffrain-Rea ML, Ciccarelli A, Valdes-Socin H, Rohmer V, Tamburrano G, Borson-Chazot C, Estour B, Ciccarelli E, Brue T, Ferolla P, Emy P, Colao A, De Menis E, Lecomte P, Penfornis F, Delemer B, Bertherat J, Wemeau JL, De Herder W, Archambeaud F, Stevenaert A, Calender A, Murat A, Cavagnini F, Beckers A (2006) Clinical characterization of familial isolated pituitary adenomas. J Clin Endocrinol Metab 91(9):3316-3323. https://doi.org/10.1210/jc.2005-2671

6. Raverot G, Arnous W, Calender A, Trouillas J, Sassolas G, Bournaud C, Pugeat M, Borson-Chazot F (2007) Familial pituitary adenomas with a heterogeneous functional pattern: clinical and genetic features. J Endocrinol Invest 30(9):787-790. https://doi. org/10.1007/bf03350819

7. Melmed S, Casanueva FF, Hoffman AR, Kleinberg DL, Montori VM, Schlechte JA, Wass JAH (2011) Diagnosis and treatment of hyperprolactinemia: an endocrine society clinical practice guideline. J Clin Endocrinol Metab 96(2):273-288. https://doi. org/10.1210/jc.2010-1692

8. Karavitaki N, Dobrescu R, Byrne JV, Grossman AB, Wass JA (2013) Does hypopituitarism recover when macroprolactinomas are treated with cabergoline? Clin Endocrinol 79(2):217-223. https://doi.org/10.1111/cen.12124

9. dos Santos Nunes V, El Dib R, Boguszewski CL, Nogueira CR (2011) Cabergoline versus bromocriptine in the treatment of hyperprolactinemia: a systematic review of randomized controlled trials and meta-analysis. Pituitary 14(3):259-265. https ://doi.org/10.1007/s11102-010-0290-z

10. Webster J, Piscitelli G, Polli A, Ferrari CI, Ismail I, Scanlon MF (1994) A comparison of cabergoline and bromocriptine in the treatment of hyperprolactinemic amenorrhea. Cabergoline Comparative Study Group. N Engl J Med 331(14):904-909. https ://doi.org/10.1056/nejm199410063311403

11. Verhelst J, Abs R, Maiter D, van den Bruel A, Vandeweghe M, Velkeniers B, Mockel J, Lamberigts G, Petrossians P, Coremans P, Mahler C, Stevenaert A, Verlooy J, Raftopoulos C, Beckers A (1999) Cabergoline in the treatment of hyperprolactinemia: a study in 455 patients. J Clin Endocrinol Metab 84(7):2518-2522. https://doi.org/10.1210/jcem.84.7.5810

12. Di Sarno A, Landi ML, Marzullo P, Di Somma C, Pivonello R, Cerbone G, Lombardi G, Colao A (2000) The effect of quinagolide and cabergoline, two selective dopamine receptor type 2 agonists, in the treatment of prolactinomas. Clin Endocrinol 53(1):53-60

13. Eguchi K, Kawamoto K, Uozumi T, Ito A, Arita K, Kurisu K (1995) Effect of cabergoline, a dopamine agonist, on estrogeninduced rat pituitary tumors: in vitro culture studies. Endocr J 42(3):413-420

14. Wang AT, Mullan RJ, Lane MA, Hazem A, Prasad C, Gathaiya NW, Fernandez-Balsells MM, Bagatto A, Coto-Yglesias F, Carey J, Elraiyah TA, Erwin PJ, Gandhi GY, Montori VM, Murad MH (2012) Treatment of hyperprolactinemia: a systematic review and meta-analysis. Syst Rev 1:33. https://doi. org/10.1186/2046-4053-1-33

15. Maiter D (2019) Management of dopamine agonist-resistant prolactinoma. Neuroendocrinology. https://doi.org/10.1159/00049 5775

16. Gillam MP, Molitch ME, Lombardi G, Colao A (2006) Advances in the treatment of prolactinomas. Endocr Rev 27(5):485-534. https://doi.org/10.1210/er.2005-9998

17. Ono M, Miki N, Kawamata T, Makino R, Amano K, Seki T, Kubo O, Hori T, Takano K (2008) Prospective study of high-dose cabergoline treatment of prolactinomas in 150 patients. J Clin Endocrinol Metab 93(12):4721-4727. https://doi.org/10.1210/ jc. 2007-2758

18. Vroonen L, Jaffrain-Rea ML, Petrossians P, Tamagno G, Chanson P, Vilar L, Borson-Chazot F, Naves LA, Brue T, Gatta B, 
Delemer B, Ciccarelli E, Beck-Peccoz P, Caron P, Daly AF, Beckers A (2012) Prolactinomas resistant to standard doses of cabergoline: a multicenter study of 92 patients. Eur J Endocrinol 167(5):651-662. https://doi.org/10.1530/eje-12-0236

19. Etienne D, Dominique M, Julian D (1996) Effects of the dopamine agonist cabergoline in patients with prolactinoma intolerant or resistant to bromocriptine. Eur J Endocrinol 134(4):454-456. https://doi.org/10.1530/eje.0.1340454

20. Delgrange E, Duprez T, Maiter D (2006) Influence of parasellar extension of macroprolactinomas defined by magnetic resonance imaging on their responsiveness to dopamine agonist therapy. Clin Endocrinol 64(4):456-462. https://doi.org/10.111 1/j.1365-2265.2006.02493.x

21. Vasilev V, Daly AF, Vroonen L, Zacharieva S, Beckers A (2011) Resistant prolactinomas. J Endocrinol Invest 34(4):312-316

22. Delgrange E, Daems T, Verhelst J, Abs R, Maiter D (2009) Characterization of resistance to the prolactin-lowering effects of cabergoline in macroprolactinomas: a study in 122 patients. Eur $\mathbf{J}$ Endocrinol 160(5):747-752. https://doi.org/10.1530/eje-09-0012

23. Wu ZR, Zhang Y, Cai L, Lin SJ, Su ZP, Wei YX, Shang HB, Yang WL, Zhao WG, Wu ZB (2016) Long-term clinical outcomes of invasive giant prolactinomas after a mean ten-year followup. Int J Endocrinol 2016:7. https://doi.org/10.1155/2016/8580750

24. Salenave S, Ancelle D, Bahougne T, Raverot G, Kamenicky P, Bouligand J, Guiochon-Mantel A, Linglart A, Souchon PF, Nicolino M, Young J, Borson-Chazot F, Delemer B, Chanson P (2015) Macroprolactinomas in children and adolescents: factors associated with the response to treatment in 77 patients. J Clin Endocrinol Metab 100(3):1177-1186. https://doi.org/10.1210/ jc.2014-3670

25. Mallea-Gil MS, Cristina C, Perez-Millan MI, Villafane AM, Ballarino C, Stalldecker G, Becu-Villalobos D (2009) Invasive giant prolactinoma with loss of therapeutic response to cabergoline: expression of angiogenic markers. Endocr Pathol 20(1):35-40. https://doi.org/10.1007/s12022-009-9057-3

26. Pellegrini I, Rasolonjanahary R, Gunz G, Bertrand P, Delivet S, Jedynak CP, Kordon C, Peillon F, Jaquet P, Enjalbert A (1989) Resistance to bromocriptine in prolactinomas. J Clin Endocrinol Metab 69(3):500-509. https://doi.org/10.1210/jcem-69-3-500

27. Caccavelli L, Morange-Ramos I, Kordon C, Jaquet P, Enjalbert A (1996) Alteration of G alpha subunits mRNA levels in bromocriptine resistant prolactinomas. J Neuroendocrinol 8(10):737-746

28. Passos VQ, Fortes MA, Giannella-Neto D, Bronstein MD (2009) Genes differentially expressed in prolactinomas responsive and resistant to dopamine agonists. Neuroendocrinology 89(2):163170. https://doi.org/10.1159/000156116

29. Hu B, Mao Z, Du Q, Jiang X, Wang Z, Xiao Z, Zhu D, Wang X, Zhu Y, Wang H (2019) miR-93-5p targets Smad7 to regulate the transforming growth factor-beta1/Smad3 pathway and mediate fibrosis in drug-resistant prolactinoma. Brain Res Bull 149:21-31. https://doi.org/10.1016/j.brainresbull.2019.03.013

30. Delgrange E, Crabbe J, Donckier J (1998) Late development of resistance to bromocriptine in a patient with macroprolactinoma. Horm Res 49(5):250-253. https://doi.org/10.1159/000023180

31. Behan LA, Draman MS, Moran C, King T, Crowley RK, O'Sullivan EP, Smith D, Thompson CJ, Agha A (2011) Secondary resistance to cabergoline therapy in a macroprolactinoma: a case report and literature review. Pituitary 14(4):362-366. https ://doi.org/10.1007/s11102-009-0168-0

32. Breidahl HD, Topliss DJ, Pike JW (1983) Failure of bromocriptine to maintain reduction in size of a macroprolactinoma. Br Med J 287(6390):451-452. https://doi.org/10.1136/ bmj.287.6390.451
33. McCall D, Hunter SJ, Cooke RS, Herron B, Sheridan B, Atkinson $\mathrm{AB}$ (2007) Unusual late development of dopamine agonist resistance in two women with hyperprolactinaemia associated with transition from micro to macroadenoma. Clin Endocrinol 66(1):149-150. https://doi.org/10.1111/j.1365-2265.2006.02686 . $\mathrm{x}$

34. Alberiche Ruano M, Boronat Cortes M, Ojeda Pino A, Rodriguez Perez C, Gracia Nunez M, Marrero Arencibia D, Novoa Mogollon FJ (2010) Acquired resistance to cabergoline: progression from initially responsive micro to macroprolactinoma. Pituitary 13(4):380-382. https://doi.org/10.1007/s11102-010-0237-4

35. Sbardella E, Farah G, Fathelrahman A, Cudlip S, Ansorge O, Karavitaki N, Grossman AB (2016) A macroprolactinoma becoming resistant to cabergoline and developing atypical pathology. Endocrinol Diabetes Metab Case Rep. https://doi. org/10.1530/edm-16-0038

36. Colao A, Di Sarno A, Sarnacchiaro F, Ferone D, Di Renzo G, Merola B, Annunziato L, Lombardi G (1997) Prolactinomas resistant to standard dopamine agonists respond to chronic cabergoline treatment. J Clin Endocrinol Metab 82(3):876-883. https ://doi.org/10.1210/jcem.82.3.3822

37. Wang C, Bai M, Wang X, Tan C, Zhang D, Chang L, Li G, Xie L, Su J, Wen Y (2018) Estrogen receptor antagonist fulvestrant inhibits proliferation and promotes apoptosis of prolactinoma cells by regulating the IRE1/XBP1 signaling pathway. Mol Med Rep 18(4):4037-4041. https://doi.org/10.3892/mmr.2018.9379

38. Donegan D, Atkinson JLD, Jentoft M, Natt N, Nippoldt TB, Erickson B, Meyer F, Erickson D (2016) Surgical outcomes of prolactinomas in recent era: results of a heterogenous group. Endocr Pract 23(1):37-45. https://doi.org/10.4158/EP161446.OR

39. Primeau V, Raftopoulos C, Maiter D (2012) Outcomes of transsphenoidal surgery in prolactinomas: improvement of hormonal control in dopamine agonist-resistant patients. Eur J Endocrinol 166(5):779-786. https://doi.org/10.1530/eje-11-1000

40. Loeffler JS, Shih HA (2011) Radiation therapy in the management of pituitary adenomas. J Clin Endocrinol Metab 96(7):1992-2003. https://doi.org/10.1210/jc.2011-0251

41. Olarescu NC, Perez-Rivas LG, Gatto F, Cuny T, Tichomirowa MA, Tamagno G, Gahete MD (2019) Aggressive and malignant prolactinomas. Neuroendocrinology. https://doi. org/10.1159/000497205

42. Marleen K, Ferdinand R, Johannes AR, Alberto MP (2006) Malignant prolactinoma: case report and review of the literature. Eur J Endocrinol 155(4):523-534. https://doi.org/10.1530/ eje. 1.02268

43. Nieman LK, Biller BMK, Findling JW, Murad MH, Newell-Price J, Savage MO, Tabarin A (2015) Treatment of cushing's syndrome: an endocrine society clinical practice guideline. J Clin Endocrinol Metab 100(8):2807-2831. https://doi.org/10.1210/ jc. $2015-1818$

44. Katznelson L, Laws ER Jr, Melmed S, Molitch ME, Murad MH, Utz A, Wass JAH (2014) Acromegaly: an endocrine society clinical practice guideline. J Clin Endocrinol Metab 99(11):39333951. https://doi.org/10.1210/jc.2014-2700

45. Beck-Peccoz P, Lania A, Beckers A, Chatterjee K, Wemeau JL (2013) 2013 European thyroid association guidelines for the diagnosis and treatment of thyrotropin-secreting pituitary tumors. Eur Thyroid J 2(2):76-82. https://doi.org/10.1159/000351007

46. Thodou E, Kontogeorgos G, Theodossiou D, Pateraki M (2006) Mapping of somatostatin receptor types in GH or/and PRL producing pituitary adenomas. J Clin Pathol 59(3):274-279. https ://doi.org/10.1136/jcp.2005.026914

47. Fusco A, Gunz G, Jaquet P, Dufour H, Germanetti AL, Culler MD, Barlier A, Saveanu A (2008) Somatostatinergic ligands in 
dopamine-sensitive and -resistant prolactinomas. Eur J Endocrinol 158(5):595-603. https://doi.org/10.1530/eje-07-0806

48. Jaquet P, Ouafik L, Saveanu A, Gunz G, Fina F, Dufour H, Culler MD, Moreau JP, Enjalbert A (1999) Quantitative and functional expression of somatostatin receptor subtypes in human prolactinomas1. J Clin Endocrinol Metab 84(9):3268-3276. https://doi. org/10.1210/jcem.84.9.5962

49. Sosa-Eroza E, Espinosa E, Ramírez-Rentería C, Mendoza V, Arreola R, Mercado M (2018) Treatment of multiresistant prolactinomas with a combination of cabergoline and octreotide LAR. Endocrine 61(2):343-348. https://doi.org/10.1007/s1202 0-018-1638-9

50. Fusco A, Lugli F, Sacco E, Tilaro L, Bianchi A, Angelini F, Tofani A, Barini A, Lauriola L, Maira G, Pontecorvi A, de Marinis L (2011) Efficacy of the combined cabergoline and octreotide treatment in a case of a dopamine-agonist resistant macroprolactinoma. Pituitary 14(4):351-357. https://doi. org/10.1007/s11102-008-0162-y

51. Walker JD, Grossman A, Anderson JV, Ur E, Trainer PJ, Benn J, Lowy C, Sonksen PH, Plowman PN, Lowe DG et al (1993) Malignant prolactinoma with extracranial metastases: a report of three cases. Clin Endocrinol 38(4):411-419

52. Baldari S, Ferraù F, Alafaci C, Herberg A, Granata F, Militano V, Salpietro FM, Trimarchi F, Cannavò S (2012) First demonstration of the effectiveness of peptide receptor radionuclide therapy (PRRT) with 111In-DTPA-octreotide in a giant PRL-secreting pituitary adenoma resistant to conventional treatment. Pituitary 15(1):57-60. https://doi.org/10.1007/s11102-011-0373-5

53. Giuffrida G, Ferrau F, Laudicella R, Cotta OR, Messina E, Granata F, Angileri FF, Vento A, Alibrandi A, Baldari S, Cannavo S (2019) Peptide receptor radionuclide therapy for aggressive pituitary tumors: a monocentric experience. Endocr Connect 8(5):528-535. https://doi.org/10.1530/EC-19-0065

54. Hofland LJ, Hoek JVD, Koetsveld PMV, Herder WWD, Waaijers M, Sprij-Mooij D, Bruns C, Weckbecker G, Feelders R, Lely AJVD, Beckers A, Lamberts SW, Hofland LJ, Hoek JVD, Koetsveld PMV, Herder WWD, Waaijers M, Sprij-Mooij D, Bruns C, Weckbecker G, Feelders R, Lely AJVD, Beckers A, Lamberts SW (2004) The novel somatostatin analog SOM230 is a potent inhibitor of hormone release by growth hormone- and prolactinsecreting pituitary adenomas in vitro. J Clin Endocrinol Metab 89:1577-1585

55. Ibanez-Costa A, Rivero-Cortes E, Vazquez-Borrego MC, Gahete MD, Jimenez-Reina L, Venegas-Moreno E, de la Riva A, Arraez MA, Gonzalez-Molero I, Schmid HA, Maraver-Selfa S, GavilanVillarejo I, Garcia-Arnes JA, Japon MA, Soto-Moreno A, Galvez MA, Luque RM, Castano JP (2016) Octreotide and pasireotide (dis)similarly inhibit pituitary tumor cells in vitro. J Endocrinol 231(2):135-145. https://doi.org/10.1530/joe-16-0332

56. Lasolle H, Vasiljevic A, Borson-Chazot F, Raverot G (2019) Pasireotide: A potential therapeutic alternative for resistant prolactinoma. Ann Endocrinol 80(2):84-88. https://doi. org/10.1016/j.ando.2018.07.013

57. Coopmans EC, van Meyel SWF, Pieterman KJ, van Ipenburg JA, Hofland L, Donga E, Daly AF, Beckers A, Van der Lely AJ, Neggers S (2019) Excellent response to pasireotide therapy in an aggressive and dopamine-resistant prolactinoma. Eur J Endocrinol. https://doi.org/10.1530/eje-19-0279

58. Rocheville M, Lange DC, Kumar U, Patel SC, Patel RC, Patel YC (2000) Receptors for dopamine and somatostatin: formation of hetero-oligomers with enhanced functional activity. Science 288(5463):154-157

59. Murai I, Ben-Jonathan N (1990) Acute stimulation of prolactin release by estradiol: mediation by the posterior pituitary. Endocrinology 126(6):3179-3184. https://doi.org/10.1210/ endo-126-6-3179
60. Heaney AP, Horwitz GA, Wang Z, Singson R, Melmed S (1999) Early involvement of estrogen-induced pituitary tumor transforming gene and fibroblast growth factor expression in prolactinoma pathogenesis. Nat Med 5(11):1317-1321. https://doi. org/10.1038/15275

61. Scheithauer BW, Sano T, Kovacs KT, Young WF, Ryan N, Randall RV (1990) The pituitary gland in pregnancy: a clinicopathologic and immunohistochemical study of 69 cases. Mayo Clin Proc 65(4):461-474. https://doi.org/10.1016/S0025 -6196(12)60946-X

62. Delgrange E, Vasiljevic A, Wierinckx A, Francois P, Jouanneau E, Raverot G, Trouillas J (2015) Expression of estrogen receptor alpha is associated with prolactin pituitary tumor prognosis and supports the sex-related difference in tumor growth. Eur J Endocrinol 172(6):791-801. https://doi.org/10.1530/ eje-14-0990

63. Volker W, Gehring WG, Berning R, Schmidt RC, Schneider J, von zur Muhlen A (1982) Impaired pituitary response to bromocriptine suppression: reversal after bromocriptine plus tamoxifen. Acta Endocrinol 101(4):491-500

64. Lamberts SW, de Quijada M, Klijn JG (1980) The effect of tamoxifen on GH and PRL secretion by human pituitary tumors. J Endocrinol Invest 3(4):343-347. https://doi.org/10.1007/bf033 49368

65. Lamberts SW, Verleun T, Oosterom R (1982) Effect of tamoxifen administration on prolactin release by invasive prolactin-secreting pituitary adenomas. Neuroendocrinology 34(5):339-342. https://doi.org/10.1159/000123324

66. Choudhary C, Hamrahian AH, Bena JF, Recinos P, Kennedy L, Dobri G (2019) The effect of raloxifene on serum prolactin level in patients with prolactinoma. Endocr Pract. https://doi. org/10.4158/ep-2018-0321

67. Cao L, Gao H, Gui S, Bai G, Lu R, Wang F, Zhang Y (2014) Effects of the estrogen receptor antagonist fulvestrant on F344 rat prolactinoma models. J Neurooncol 116(3):523-531. https:// doi.org/10.1007/s11060-013-1351-8

68. Gao H, Xue Y, Cao L, Liu Q, Liu C, Shan X, Wang H, Gu Y, Zhang Y (2017) ESR1 and its antagonist fulvestrant in pituitary adenomas. Mol Cell Endocrinol 443:32-41. https://doi. org/10.1016/j.mce.2016.12.029

69. Li C, Sun Z, Gui S, Liu F, Zhang Y (2009) Effects of fulvestrant, an estrogen receptor antagonist, on MMQ cells and its mechanism. Neuro Endocrinol Lett 30(2):268-274

70. Garcia-Barrado MJ, Blanco EJ, Iglesias-Osma MC, CarreteroHernandez M, Catalano-Iniesta L, Sanchez-Robledo V, Carretero M, Herrero JJ, Carrero S, Carretero J (2017) Relation among aromatase $\mathrm{P} 450$ and tumoral growth in human prolactinomas. Int J Mol Sci. https://doi.org/10.3390/ijms18112299

71. Akinci H, Kapucu A, Dar KA, Celik O, Tutunculer B, Sirin G, Oz B, Gazioglu N, Ince H, Aliustaoglu S, Kadioglu P (2013) Aromatase cytochrome $\mathrm{P} 450$ enzyme expression in prolactinomas and its relationship to tumor behavior. Pituitary 16(3):386392. https://doi.org/10.1007/s11102-012-0436-2

72. Carretero J, Burks DJ, Vazquez G, Rubio M, Hernandez E, Bodego P, Vazquez R (2002) Expression of aromatase P450 is increased in spontaneous prolactinomas of aged rats. Pituitary 5(1):5-10

73. Garcia Barrado MJ, Blanco EJ, Carretero Hernandez M, Iglesias Osma MC, Carretero M, Herrero JJ, Burks DJ, Carretero J (2014) Local transformations of androgens into estradiol by aromatase P450 is involved in the regulation of prolactin and the proliferation of pituitary prolactin-positive cells. PLoS ONE 9(6):e101403. https://doi.org/10.1371/journal.pone.0101403

74. Gillam MP, Middler S, Freed DJ, Molitch ME (2002) The novel use of very high doses of cabergoline and a combination of testosterone and an aromatase inhibitor in the treatment of a giant 
prolactinoma. J Clin Endocrinol Metab 87(10):4447-4451. https ://doi.org/10.1210/jc.2002-020426

75. Heidari Z, Hosseinpanah F, Shirazian N (2010) Achievement of fertility in an infertile man with resistant macroprolactinoma using high-dose bromocriptine and a combination of human chorionic gonadotropin and an aromatase inhibitor. Endocr Pract 16(4):669-672. https://doi.org/10.4158/ep10026.Cr

76. Jin K, Ruan L, Pu J, Zhong A, Wang F, Tan S, Huang H, Mou J, Yang G (2017) [Effect of metformin on proliferation and apoptosis of rat prolactinoma MMQ cells and related mechanisms]. $\mathrm{Xi}$ bao yu fen zi mian yi xue za zhi $=$ Chin $\mathrm{J}$ Cell Mol Immunol 33(5):643-648

77. Gao J, Liu Y, Han G, Deng K, Liu X, Bao X, Feng M, Yao Y, Lian W, Xing B, Lv X, Wang R (2018) Metformin inhibits growth and prolactin secretion of pituitary prolactinoma cells and xenografts. J Cell Mol Med 22(12):6368-6379. https://doi. org $/ 10.1111 / \mathrm{jcmm} .13963$

78. Choi YK, Park K-G (2013) Metabolic roles of AMPK and metformin in cancer cells. Mol Cells 36(4):279-287. https://doi. org/10.1007/s10059-013-0169-8

79. Liu X, Liu Y, Gao J, Feng M, Bao X, Deng K, Yao Y, Wang $\mathrm{R}$ (2018) Combination treatment with bromocriptine and metformin in patients with bromocriptine-resistant prolactinomas: pilot study. World Neurosurg 115:94-98. https://doi. org/10.1016/j.wneu.2018.02.188

80. Raverot G, Sturm N, de Fraipont F, Muller M, Salenave S, Caron P, Chabre O, Chanson P, Cortet-Rudelli C, Assaker R, Dufour $\mathrm{H}$, Gaillard S, Francois P, Jouanneau E, Passagia JG, Bernier M, Cornelius A, Figarella-Branger D, Trouillas J, Borson-Chazot F, Brue T (2010) Temozolomide treatment in aggressive pituitary tumors and pituitary carcinomas: a French multicenter experience. J Clin Endocrinol Metab 95(10):4592-4599. https://doi. org/10.1210/jc.2010-0644

81. Raverot G, Burman P, McCormack A, Heaney A, Petersenn S, Popovic V, Trouillas J, Dekkers OM (2018) European Society of Endocrinology Clinical Practice Guidelines for the management of aggressive pituitary tumours and carcinomas. Eur J Endocrinol 178(1):G1-g24. https://doi.org/10.1530/eje-17-0796

82. Losa M, Bogazzi F, Cannavo S, Ceccato F, Curto L, De Marinis L, Iacovazzo D, Lombardi G, Mantovani G, Mazza E, Minniti G, Nizzoli M, Reni M, Scaroni C (2016) Temozolomide therapy in patients with aggressive pituitary adenomas or carcinomas. J Neurooncol 126(3):519-525. https://doi.org/10.1007/s1106 0-015-1991-y

83. Chen $\mathrm{C}$, Yin $\mathrm{S}$, Zhang S, Wang $\mathrm{M}$, Hu Y, Zhou P, Jiang S (2017) Treatment of aggressive prolactinoma with temozolomide: a case report and review of literature up to date. Medicine 96(47):e8733-e8733. https://doi.org/10.1097/MD.0000000000 008733

84. McCormack A, Dekkers OM, Petersenn S, Popovic V, Trouillas J, Raverot G, Burman P (2018) Treatment of aggressive pituitary tumours and carcinomas: results of a European Society of Endocrinology (ESE) survey 2016. Eur J Endocrinol 178(3):265-276. https://doi.org/10.1530/eje-17-0933

85. Barkhoudarian G, Palejwala SK, Ogunbameru R, Wei H, Eisenberg A, Kelly DF (2018) Early recognition and initiation of temozolomide chemotherapy for refractory, invasive pituitary macroprolactinoma with long-term sustained remission. World Neurosurg 118:118-124. https://doi.org/10.1016/j. wneu.2018.07.082

86. Ceccato F, Lombardi G, Albiger N, Mazzai L, Pambuku A, Rolma G, Zagonel V, Scaroni C (2019) Temozolomide cytoreductive treatment in a giant cabergoline-resistant prolactinsecreting pituitary neuroendocrine tumor. Anticancer Drugs 30(5):533-536. https://doi.org/10.1097/cad.0000000000000768
87. Felker J, Patterson B, Wrubel D, Janss A (2016) Successful treatment of a child with a prolactin secreting macroadenoma with temozolomide. J Pediatr Endocrinol Metab 29(12):1413-1415. https://doi.org/10.1515/jpem-2016-0159

88. Fountas A, Chai ST, Ayuk J, Gittoes N, Chavda S, Karavitaki $\mathrm{N}$ (2018) A rare challenging case of co-existent craniopharyngioma, acromegaly and squamous cell lung cancer. Endocrinol Diabetes Metab Case Rep. https://doi.org/10.1530/edm-18-0018

89. Bengtsson D, Schroder HD, Berinder K, Maiter D, Hoybye C, Ragnarsson O, Feldt-Rasmussen U, Krogh Rasmussen A, van der Lely A, Petersson M, Johannsson G, Andersen M, Burman P (2018) Tumoral MGMT content predicts survival in patients with aggressive pituitary tumors and pituitary carcinomas given treatment with temozolomide. Endocrine 62(3):737-739. https://doi.org/10.1007/s12020-018-1751-9

90. Murakami M, Mizutani A, Asano S, Katakami H, Ozawa Y, Yamazaki K, Ishida Y, Takano K, Okinaga H, Matsuno A (2011) A mechanism of acquiring temozolomide resistance during transformation of atypical prolactinoma into prolactin-producing pituitary carcinoma: case report. Neurosurgery 68(6):E1761-1767. https://doi.org/10.1227/NEU.0b013e3182 17161a. discussion E1767

91. Lasolle H, Cortet C, Castinetti F, Cloix L, Caron P, Delemer B, Desailloud R, Jublanc C, Lebrun-Frenay C, Sadoul JL, Taillandier L, Batisse-Lignier M, Bonnet F, Bourcigaux N, Bresson D, Chabre O, Chanson P, Garcia C, Haissaguerre M, Reznik Y, Borot S, Villa C, Vasiljevic A, Gaillard S, Jouanneau E, Assie G, Raverot G (2017) Temozolomide treatment can improve overall survival in aggressive pituitary tumors and pituitary carcinomas. Eur J Endocrinol 176(6):769-777. https://doi. org/10.1530/eje-16-0979

92. Bengtsson D, Schrøder HD, Andersen M, Maiter D, Berinder K, Feldt Rasmussen U, Rasmussen ÅK, Johannsson G, Hoybye $\mathrm{C}$, van der Lely AJ, Petersson M, Ragnarsson O, Burman P (2015) Long-term outcome and MGMT as a predictive marker in 24 patients with atypical pituitary adenomas and pituitary carcinomas given treatment with temozolomide. J Clin Endocrinol Metab 100(4):1689-1698. https://doi.org/10.1210/ jc. 2014-4350

93. McCormack AI, Wass JA, Grossman AB (2011) Aggressive pituitary tumours: the role of temozolomide and the assessment of MGMT status. Eur J Clin Invest 41(10):1133-1148. https:// doi.org/10.1111/j.1365-2362.2011.02520.x

94. Kaltsas GA, Mukherjee JJ, Plowman PN, Monson JP, Grossman AB, Besser GM (1998) The role of cytotoxic chemotherapy in the management of aggressive and malignant pituitary tumors. J Clin Endocrinol Metab 83(12):4233-4238. https://doi. org/10.1210/jcem.83.12.5300

95. Petterson T, MacFarlane IA, MacKenzie JM, Shaw MD (1992) Prolactin secreting pituitary carcinoma. J Neurol Neurosurg Psychiatry 55(12):1205. https://doi.org/10.1136/jnnp.55.12.1205

96. Pernicone PJ, Scheithauer BW, Sebo TJ, Kovacs KT, Horvath E, Young WF Jr, Lloyd RV, Davis DH, Guthrie BL, Schoene WC (1997) Pituitary carcinoma. Cancer 79(4):804-812

97. Ben-Shlomo A, Cooper O (2017) Role of tyrosine kinase inhibitors in the treatment of pituitary tumours: from bench to bedside. Curr Opin Endocrinol Diabetes Obes 24(4):301-305. https://doi. org/10.1097/MED.0000000000000344

98. Cooper O, Vlotides G, Fukuoka H, Greene MI, Melmed S (2011) Expression and function of ErbB receptors and ligands in the pituitary. Endocr Relat Cancer 18(6):R197-211. https://doi. org/10.1530/erc-11-0066

99. Cooper O, Mamelak A, Bannykh S, Carmichael J, Bonert V, Lim S, Cook-Wiens G, Ben-Shlomo A (2014) Prolactinoma ErbB receptor expression and targeted therapy for aggressive 
tumors. Endocrine 46(2):318-327. https://doi.org/10.1007/s1202 0-013-0093-x

100. Fukuoka H, Cooper O, Mizutani J, Tong Y, Ren SG, Bannykh S, Melmed S (2011) HER2/ErbB2 receptor signaling in rat and human prolactinoma cells: strategy for targeted prolactinoma therapy. Mol Endocrinol (Baltimore, Md.) 25(1):92-103. https ://doi.org/10.1210/me.2010-0353

101. Targeted therapy with lapatinib in patients with recurrent pituitary tumors resistant to standard therapy. https://ClinicalTrials. gov/show/NCT00939523.

102. Su Z, Cai L, Lu J, Li C, Gui S, Liu C, Wang C, Li Q, Zhuge Q, Zhang Y (2017) Global expression profile of tumor stem-like cells isolated from MMQ rat prolactinoma cell. Cancer Cell Int 17:15. https://doi.org/10.1186/s12935-017-0390-1

103. Ortiz LD, Syro LV, Scheithauer BW, Ersen A, Uribe H, Fadul CE, Rotondo F, Horvath E, Kovacs K (2012) Anti-VEGF therapy in pituitary carcinoma. Pituitary 15(3):445-449. https://doi. org/10.1007/s11102-011-0346-8

104. Touma W, Hoostal S, Peterson RA, Wiernik A, SantaCruz KS, Lou E (2017) Successful treatment of pituitary carcinoma with concurrent radiation, temozolomide, and bevacizumab after resection. J Clin Neurosci 41:75-77. https://doi.org/10.1016/j. jocn.2017.02.052

105. Sabatini DM (2006) mTOR and cancer: insights into a complex relationship. Nat Rev Cancer 6(9):729-734. https://doi. org/10.1038/nrc1974

106. Eric M, Kyle J, Toru T, Sameer A, Sylvia LA, Shereen E, Gelareh Z (2014) The PI3K/AKT/mTOR pathway in the pathophysiology and treatment of pituitary adenomas. Endocr Relat Cancer 21(4):R331-R344. https://doi.org/10.1530/ERC-14-0188

107. Gorvin CM, Newey PJ, Rogers A, Stokes V, Neville MJ, Lines KE, Ntali G, Lees P, Morrison PJ, Singhellakis PN, Malandrinou FC, Karavitaki N, Grossman AB, Karpe F, Thakker RV (2018) Association of prolactin receptor (PRLR) variants with prolactinomas. Hum Mol Genet 28(6):1023-1037. https://doi. org/10.1093/hmg/ddy396

108. Zhang D, Way JS, Zhang X, Sergey M, Bergsneider M, Wang MB, Yong WH, Heaney AP (2019) Effect of everolimus in treatment of aggressive prolactin-secreting pituitary adenomas. J Clin Endocrinol Metab 104(6):1929-1936. https://doi.org/10.1210/ jc. 2018-02461

109. Jouanneau E, Wierinckx A, Ducray F, Favrel V, Borson-Chazot F, Honnorat J, Trouillas J, Raverot G (2012) New targeted therapies in pituitary carcinoma resistant to temozolomide. Pituitary 15(1):37-43. https://doi.org/10.1007/s11102-011-0341-0

110. Donovan LE, Arnal AV, Wang SH, Odia Y (2016) Widely metastatic atypical pituitary adenoma with mTOR pathway STK11(F298L) mutation treated with everolimus therapy. CNS Oncol 5(4):203-209. https://doi.org/10.2217/cns-2016-0011

111. Li Z, Liu Q, Li C, Zong X, Bai J, Wu Y, Lan X, Yu G, Zhang $Y$ (2015) The role of TGF-beta/Smad signaling in dopamine agonist-resistant prolactinomas. Mol Cell Endocrinol 402:64-71. https://doi.org/10.1016/j.mce.2014.12.024

112. Recouvreux MV, Camilletti MA, Rifkin DB, Diaz-Torga G (2016) The pituitary TGFbeta1 system as a novel target for the treatment of resistant prolactinomas. J Endocrinol 228(3):R7383. https://doi.org/10.1530/joe-15-0451

113. Lin SJ, Wu ZR, Cao L, Zhang Y, Leng ZG, Guo YH, Shang HB, Zhao WG, Zhang X, Wu ZB (2017) Pituitary tumor suppression by combination of cabergoline and chloroquine. J Clin Endocrinol Metab 102(10):3692-3703. https://doi.org/10.1210/ jc.2017-00627

Publisher's Note Springer Nature remains neutral with regard to jurisdictional claims in published maps and institutional affiliations. 